Collection: 3rd International Elm Conference, Florence (Italy - 2013)

"The elms after 100 years of Dutch Elm disease"

Guest Editors: A. Santini, L. Ghelardini, E. Collin, A. Solla, J. Brunet, M. Faccoli, A. Scala, S. De Vries, J. Buiteveld

\section{Ulmus laevis in the Iberian Peninsula: a review of its ecology and conservation}

\author{
Martin Venturas ${ }^{(1)}$, Pablo Fuentes-Utrilla ${ }^{(2)}$, Rosana López ${ }^{(1)}$, Ramón \\ Perea ${ }^{(1)}$, Victoria Fernández ${ }^{(1)}$, Antonio Gascó ${ }^{(3)}$, Paula Guzmán ${ }^{(1)}$, Meng \\ $\mathrm{Li}^{(1)}$, Jesús Rodríguez-Calcerrada ${ }^{(1)}$, Eva Miranda ${ }^{(1)}$, Jorge Domínguez ${ }^{(1)}$, \\ Guillermo González-Gordaliza ${ }^{(1)}$, Elena Zafra ${ }^{(1)}$, Miriam Fajardo- \\ Alcántara ${ }^{(1)}$, Juan A Martín ${ }^{(1)}$, Richard Ennos ${ }^{(4)}$, Nikos Nanos ${ }^{(1)}$, Juan J \\ Lucena $^{(5)}$, Salustiano Iglesias ${ }^{(6)}$, Carmen Collada ${ }^{(1)}$, Luis Gil $^{(1)}$
}

European white elm (Ulmus laevis Pallas) populations are scarce, small and fragmented in the Iberian Peninsula. Due to these characteristics the indigenous status of the species in the region has been questioned, whilst the species' role in Iberian riparian forest ecology has been neglected. Herein we review past studies regarding this species' distribution and ecology in the lberian Peninsula, with special emphasis on the establishment of conservation priorities. We first present a collection of palaeogeographic, historic and genetic data suggesting that the Iberian Peninsula was a glacial refuge for $U$. lae$v i s$. Secondly, we analyse $U$. laevis distribution in relation to soil physicochemical properties and water availability in Spain. Following this, we focus on the reproductive biology of the species, and investigate the effect of masting and empty seed production on predation and regeneration establishment. Finally, based on this knowledge, we propose conservation policies for $U$. laevis in the Iberian Peninsula.

Keywords: Elm Conservation, Drought-stress Vulnerability, Root Iron Uptake, Population Genetics, Seed Dispersal, Seed Predation, Ulmus laevis' Distribution

\section{Introduction}

The European white elm (Ulmus laevis Pallas) is a hardwood deciduous tree which grows in river margins and damp bottomland forests, tolerating flooding for some periods

of the year (Collin et al. 2000). Ulmus laevis belongs to section Blepharocarpus (Wiegrefe et al. 1994), in contrast to the other two native European elms, U. minor Mill. and $U$. glabra Huds., which belong to the Ulmus

(1) GENFOR, Grupo de Investigación en Genética y Fisiología Forestal, E.T.S.I. Montes, Universidad Politécnica de Madrid, Ciudad Universitaria s/n, E-28040 Madrid (Spain); (2) ARK-Genomics, The Roslin Institute, University of Edinburgh, Easter Bush, EH25 9RG Edinburgh (UK); (3) IE University, Cardenal Zúñiga 12, E-40003 Segovia (Spain); (4) Institute of Evolutionary Biology, University of Edinburgh, West Mains Rd., EH9 9JT Edinburgh (UK); (5) Departamento de Química Agrícola, Facultad de Ciencias, Universidad Autónoma de Madrid, E-28049 Madrid (Spain); (6) Dirección General Desarrollo Rural y Política Forestal, Ministerio de Agricultura, Alimentación y Medio Ambiente, Madrid (Spain)

(a) Martin Venturas (martin.venturas@upm.es)

Received: Dec 13, 2013 - Accepted: Mar 01, 2014

Citation: Venturas M, Fuentes-Utrilla P, López R, Perea R, Fernández V, Gascó A, Guzmán P, Li M, Rodríguez-Calcerrada J, Miranda E, Domínguez J, González-Gordaliza G, Zafra E, Fajardo-Alcántara M, Martín JA, Ennos R, Nanos N, Lucena JJ, Iglesias S, Collada C, Gil L, 2015. Ulmus laevis in the Iberian Peninsula: a review of its ecology and conservation. iForest 8: 135-142 [online 2014-08-07] URL: http://www.sisef.it/iforest/contents/? id=ifor $1201-008$

Communicated by: Alberto Santini section. Ulmus laevis has been considered to be naturally distributed across Europe, from Ural Mountains to eastern France, and from southern Finland to the Caucasus, Balkans and southern France (Collin 2003). The loss of suitable habitats due to human-induced changes in riparian forests, combined with the effect of Dutch elm disease (DED), has compromised the survival of many $U$. laevis populations (Collin 2003). It is estimated that only $1 \%$ of the elms still remain alive in Germany (Mackenthun 2004), whereas the white elm is considered an endangered species in northern Belgium (Vander Mijnsbrugge et al. 2005), southern France (Timbal $\&$ Collin 1999), and Finland (Collin et al. 2004, Vakkari et al. 2009). Moreover, many small isolated populations throughout its distribution range are at risk of genetic drift (Collin 2003). As such, this species has been identified as needing specific conservation measures in Europe (Collin et al. 2004).

According to Flora Ibérica (Navarro \& Castroviejo 1993), U. laevis is an established alien species in Spain which was introduced as an ornamental; a conclusion based on its small population sizes and scarcity. This is the opinion which has prevailed among botanists, and thus, limited efforts were initially undertaken towards white elm conservation in Spain. However, the presence of U. laevis in Spain was cited for the first time by Lapeyrouse (1813) in the Pyrenees. Following this, it was also observed in Asturias (Pastor 1853), and as a result, was included in the first Iberian Floras (Willkomm \& Lange 1861, Amo 1871). Nevertheless, other botanical studies failed to include this species (Costa 1864, Loscos \& Pardo 1866, Laguna \& de Ávila 1883, Ceballos 1966, Ruíz de la Torre 1971) or considered it as an introduced species (Casadevall \& Font i Quer 1933). More recently, attending to several white elm stand characteristics, certain authors considered that $U$. laevis could be native to the Iberian Peninsula (Segura 1973, Aizpuru et al. 1999).

Following the second DED pandemic (Brasier 2000), several small, scattered, previously unknown populations of $U$. laevis were detected during the field surveys carried out by the Spanish Elm Conservation and Breeding Programme (SECBP, Technical University of Madrid, Spanish Environmental Ministry - Fig. 1). The location and characteristics of some of these newly located populations indicated that human introduction was highly unlikely. The fact that 41 of these 52 stands had not been previously detected was quite surprising, but can be explained by: (i) some stands growing in difficult access areas; (ii) difficulty in distinguishing $U$. laevis from field elm (U. minor) or wych elm (U. glabra) morphologically, unless the tree has flowers or fruits; and (iii) lack of interest 


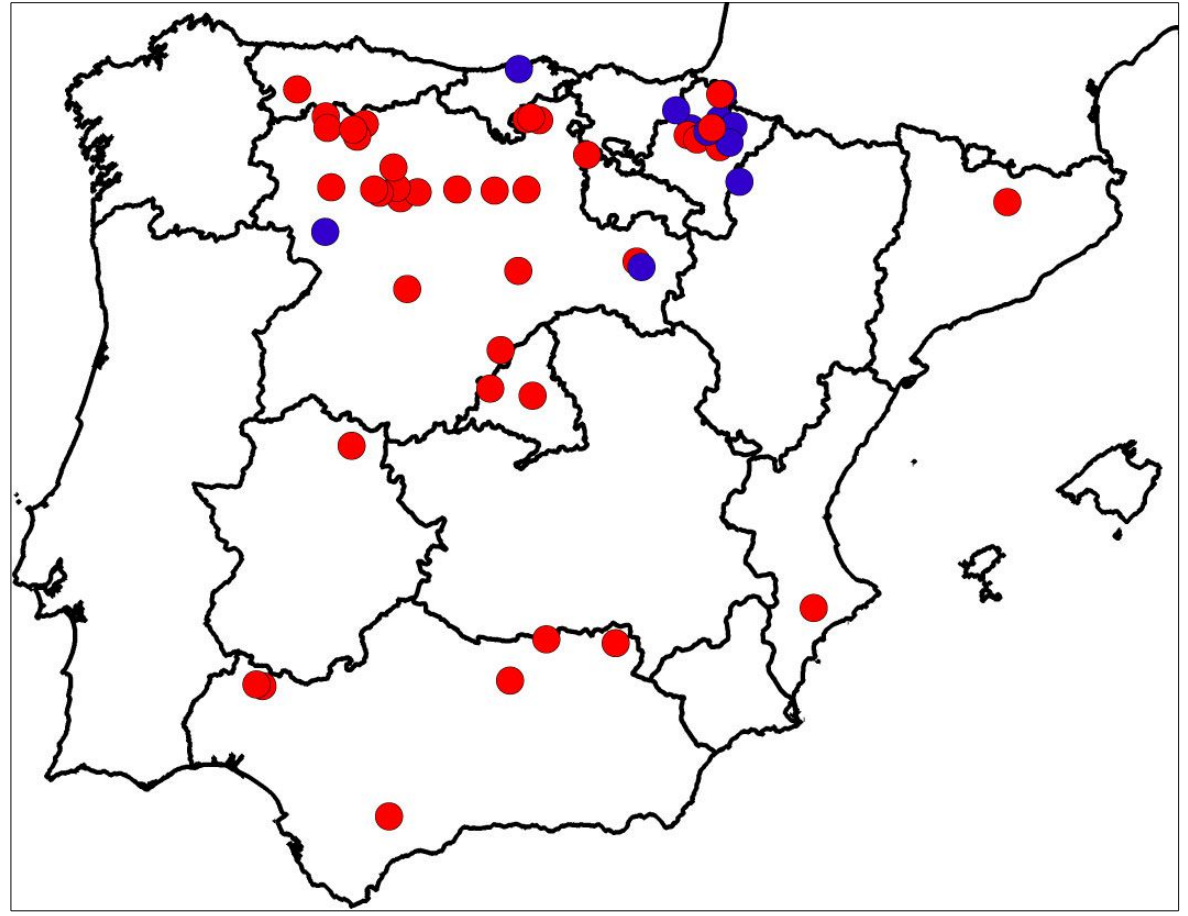

Fig. 1 - Distribution of Ulmus laevis populations in Spain. Populations previously cited in the literature (blue dots) are differentiated from those detected by the Spanish Elm Conservation and Breeding Programme (red dots). Modified from Venturas et al. (2013a).

in reporting its presence, given that it was considered an alien species. In addition, $U$. laevis trees were more easily detected after DED pandemics because they remained alive, whereas other elms died. Despite white elms being highly susceptible to DED (Pinon et al. 2005, Solla et al. 2005) they can survive the disease by an escape mechanism: bark beetles (Scolytus spp.), the propagation vectors of DED, prefer feeding on U. minor and U. pumila L. (Webber \& Kirby 1983, Webber 2004) due to the chemical composition of their bark (Pajares et al. 2004, Martín-Benito et al. 2005).

Determining whether or not small marginal populations of a species are native is complicated, especially in Mediterranean riparian forests, as they have been deeply transformed by humans over the last 4000 years (Hooke 2006, Valbuena-Carabaña et al. 2010). Indeed, all elm species were initially considered to be introduced in the Iberian Peninsula due to the lack of evidence for their presence in the first fossil records (Huntley \& Birks 1983). Following this, and based on taxonomic traits, Richens \& Jeffers (1986) established that U. glabra was native to northern Spain, and considered that if $U$. minor was to be indigenous, it would only be so in the eastern half of the Iberian Peninsula. When the number of palaeobotanic records increased and Ulmus spp. pollen was found all over Spain (Gil \& García-Nieto 1990, López 2003), fossil remains were assumed to belong to U. glabra in the moun- tain areas, and to U. minor in the lowlands. Contrary to the hypothesis put forth by Richens \& Jeffers (1986), palaeobotanic remains which appeared in non-mountainous areas of western Spain were assumed to be from U. minor, despite the fact that pollen and wood from European elms cannot be morphologically distinguished at species level (Schweingruber 1990, Stafford 1995). Therefore, after the discovery of new U. laevis populations, the following question arose: could part of the pollen from western Spain belong to U. laevis?

Herein, we review the process followed by SECBP to demonstrate the nativeness of $U$. laevis in Spain, and the species' natural distribution, ecology, conservation status and recovery possibilities.

\section{Nativeness of $\boldsymbol{U}$. laevis in the Iberian Peninsula}

Neutral genetic markers have proved to be useful when it comes to determining the status of populations of uncertain origin. Iberian native tree populations are usually genetically differentiated from central and eastern European populations, due to isolation and limited gene flow between Pleistocene discrete glacial refugia (e.g., King \& Ferris 1998, Petit et al. 2002, Heuertz et al. 2004, Magrí et al. 2006). In contrast, introduced populations normally show lower genetic diversity than the populations from which they originate, and lack private alleles (Stone \& Sunnucks 1993).
Ulmus laevis genetic diversity is relatively low compared to those of other tree species (Machon et al. 1995, 1997, Whiteley 2004, Vakkari et al. 2009, Nielsen \& Kjær 2010). Only three chloroplast haplotypes have been identified across Europe (Whiteley 2004): haplotype $A$, the high frequency one which extends all over Europe, and two rare ones, haplotype $B$, restricted to southern France, and haplotype $C$, located in the Balkans and southwest Russia. Whiteley (2004) argued that this haplotype distribution was congruent with white elm expansion from a core glacial refugium in Russia, as proposed by Huntley \& Birks (1983), but that this could also indicate the existence of additional refugia in southern European peninsulas.

Building on previously existing information (Whiteley et al. 2003a, Whiteley 2004), 20 populations from central Europe, southern France and Spain were sampled in order to determine whether Iberian populations of $U$. laevis were native (Fuentes-Utrilla 2008, Fuentes-Utrilla et al. 2014). Chloroplast (cpDNA) restriction fragment length polymorphism (RFLP) and nuclear (nDNA) microsatellite markers were analyzed. Genetic diversity indexes were calculated, and Bayesian clustering and demographic analyses were performed.

The native status of $U$. laevis in the Iberian Peninsula was supported by: (i) diversity levels, which were low but similar to other European populations; (ii) the presence of haplotypes $A$ and $B$, and of nDNA private alleles in Spain; (iii) genetic differentiation and spatial genetic structure of Spanish populations; and (iv) demographic analyses which showed signs of an ancestral bottleneck (Fuentes-Utrilla 2008, Fuentes-Utrilla et al. 2014). Moreover, there is no historic information supporting $U$. laevis introduction, nor its extensive use in Spain, contrary to what happens with $U$. minor (Gil et al. 2004) or U. pumila (Cogolludo-Agustín et al. 2000). Therefore, the Iberian Peninsula is considered to have contained some glacial refugia for U. laevis (Fuentes-Utrilla 2008, Fuentes-Utrilla et al. 2014), as also shown for other European tree taxa (Petit et al. 2002, Magrí et al. 2006). This interpretation is also consistent with the climatic modeling of the species' distribution, which identifies parts of the Iberian Peninsula suitable for $U$. laevis under both the Last Glacial Maximum and present day climates (Svenning et al. 2008).

\section{Edaphic factors and $U$. laevis distribution}

Calcicole species can grow normally on both calcareous and siliceous soils (Zohlen 2002). However, calcifuge species growing on calcareous soils suffer nutrient deficiencies due to a limited absorption of phosphorous (Tyler 1992, Zohlen \& Tyler 2004), 


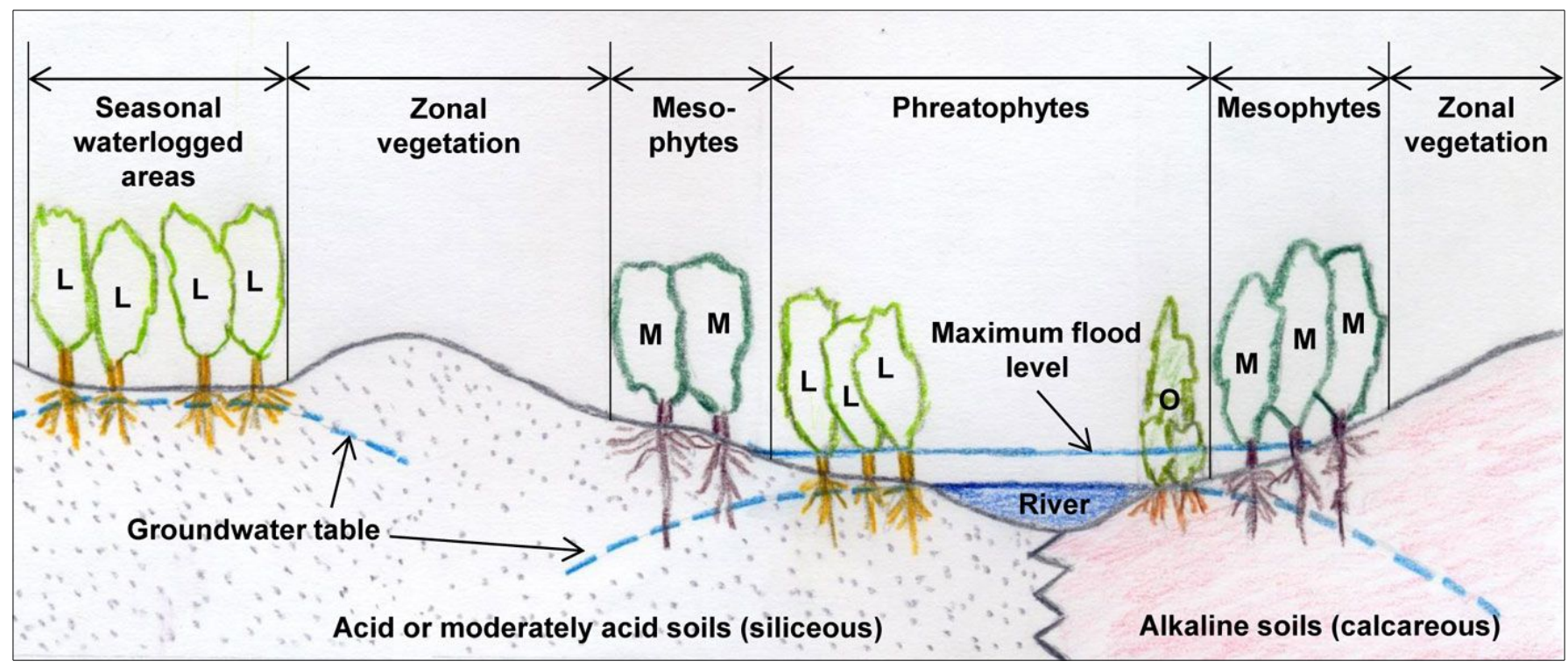

Fig. 2 - Ulmus laevis and U. minor distribution sketch in relation to soil nature and water availability. Ulmus laevis trees (L); Ulmus minor trees $(\mathrm{M})$; other phreatophytes $(\mathrm{O})$.

manganese (Messenger 1986, Thomas et al. 1998) and chiefly iron (Zohlen \& Tyler 1997, 2000, Zohlen 2002). Iron is of great importance for many metabolic and enzymatic processes (Kobayashi \& Nishizawa 2012). Iron deficiency compromises plant growth and establishment because it causes reductions in photosynthetic rates (Larbi et al. 2006). Plants have developed specialized mechanisms for increasing root iron availability and facilitating its uptake and transport within the plant (Marschner \& Römheld 1994). Elms are classified as Strategy I plants (Marschner \& Römheld 1994), and as such, their root iron uptake mechanisms are based on: (i) the production of root ferric reductase for transforming $\mathrm{Fe}^{3+}$ into $\mathrm{Fe}^{2+}$ compounds; (ii) the induction of $\mathrm{Fe}^{2+}$ membrane transporters; (iii) increasing iron solubility by acidifying the rizhosphere excreting protons $\left(\mathrm{H}^{+}\right)$; and (iv) increasing iron availability by secreting organic compounds (Abadía et al. 2011).

Ulmus laevis populations in Spain grow on siliceous moderately acid and acid soils, thus suggesting that this species has a calcifuge character within the region (Fig. 2). Ulmus minor can grow both on acid and alkaline soils, but is thought to be native to calcareous soils (Richens \& Jeffers 1986). In light of this, we tested whether differences in the efficiency of root iron uptake mechanisms may account for the differential distribution of these two species in Spain (Venturas 2013, Venturas et al. 2014a).

Seedlings from both species were grown in hydroponic culture under iron uptake limiting conditions. Their growth, degree of lime-induced chlorosis symptoms, root proton extrusion capability, and root ferric reductase activity were evaluated. Results showed that both species suffered severe lime-induced chlorosis if grown with no iron. However, re-supply of iron in U. minor led to a better mobilization of iron over the complete plant and leaf surface, whereas this was confined to young leaves and along the leaf nerves in U. laevis. Moreover, U. laevis seedlings showed a lower root proton extrusion capacity and root ferric reductase activity than U. minor. Therefore, differences in the iron acquisition mechanisms may be at least partly responsible for these species' distribution in the Iberian Peninsula, enabling $U$. minor to grow on calcareous soils where iron absorption is more limiting for $U$. laevis (Venturas 2013, Venturas et al. 2014a).

\section{Water availability and $\boldsymbol{U}$. laevis}

Ulmus laevis is a riparian tree which thrives in damp soils (Collin et al. 2000, Fig. 2 ). An association study between species composition and soil types conducted in Estonia showed that this species grows mainly in embankments where the predominant soils are Eutric Gleysols or Gleyic Fluvisols (Paal et al. 2007). It has also been observed that U. laevis has better survival and growth rates than U. minor in heavy clay soils with prolonged waterlogging (Ciçek et al. 2007). This indicates the high water demand and waterlogging tolerance of this elm species.

Wetland and flood-tolerant plants survive waterlogging due to complex anatomical, physiological, morphological, and life-history adaptations (Blom \& Voesenek 1996, Kozlowski 1997, Pezeshki 2001). Xylem cavitation, for example, might help stem and root oxygen supply in flooded $U$. laevis plants (Venturas et al. 2013b). In a recent study, seedlings of $U$. laevis subjected to experimental waterlogging exhibited $40 \%$ loss of root hydraulic conductivity relative to control, well-watered plants. Most likely in relation to this, stomata partly closed and net photosynthesis was reduced. Respiration rates of leaves, stems and roots increased soon after waterlogging started, so that net carbon gain at the plant level was severely diminished. However, seedlings survived two months of waterlogging and recovered normal water-transport capacity and net photosynthesis afterward. This indicated that $U$. laevis is sensitive but considerably resistant to waterlogging at the seedling stage ( $\mathrm{Li}$ et al., unpublished data).

Drought-induced hydraulic failure affects plant productivity and survival (Sperry et al. 2008, López et al. 2013, Barigah et al. 2013), and the European white elm has been shown to be highly susceptible to droughtinduced xylem cavitation (Venturas et al. 2013b). Large xylem vessels confer this species' high water transport capacity but counter its resistance to drought, thus supporting the trade-off between waterlogging and drought tolerance observed across species (Niinemets \& Valladares 2006). Therefore, the expected aridification of the Iberian Peninsula (Somot et al. 2008) could further compromise the survival of $U$. laevis populations (Allen et al. 2010, Hemery et al. 2010), as this will probably increase water demand for irrigation, causing further depletion of water tables, and increased drought episodes. A drought-stress experiment carried out with plants from France, Sweden and Germany showed that there is substantial additive genetic variation for drought adaptation in $U$. laevis populations (Black-Samuelsson et al. 2003). This has also been observed for other adaptive traits such as growth and leaf phenology (Whiteley et al. 2003b). Therefore, 
there is a genetic basis for $U$. laevis adaptation to future water availability changes (Black-Samuelsson et al. 2003, Hemery et al 2010), and Mediterranean populations may well be an important resource for breeding programmes.

\section{Reproductive ecology}

Ulmus laevis is an anemophilous, self-incompatible (Mittempergher \& La Porta 1991), and highly outcrossing species (Nielsen \& Kjær 2010). Its fruits are samaras (winged nuts) with ciliated margins, which are dispersed by both wind (anemochory) and water (hydrochory - Collin 2003). Dispersal by two or more agents (diplochory) increases dispersal benefits and decreases seed mortality probabilities (Vander Wall \& Longland 2004). Wind disperses $95 \%$ of $U$. laevis seeds at short distances (less than 30 $\mathrm{m})$, thus enabling them to reach suitable microhabitats close to mother trees, or landing on a water surface for secondary transport. In contrast, hydrochory allows long-distance gene exchange and the colorization of new sites (Venturas et al. 2014b). In some U. laevis stands, a marked spatial genetic structure can be found due to the low wind dispersal distance (Nielsen \& Kjær 2010, Venturas et al. 2013a) and the lack of secondary seed movement (Venturas et al. 2014b).

In riparian species, seed release timing is very important for seed dispersal and seedling establishment (Deiller et al. 2003, Nilsson et al. 2010). In the Iberian Peninsula samara abscission occurs from mid-April to the end of June. Therefore, samara dispersal usually occurs just after spring floods, when the conditions are optimal for seed germination and seedling establishment as the preexisting vegetation is eliminated with the floods, and mud is deposited as water returns to the main channels (López-Almansa 2004 Nilsson et al. 2010). Samara release rates mainly depend on maturity (phenology) and increase with strong winds, but not with rain (Venturas et al. 2014b). White elm seeds germinate soon after they are dispersed and show high germination rates (Ciçek \& Tilki 2005, SECBP, unpublished data)

Ulmus laevis is a masting species. A three year study performed in a population from central Spain showed that, in a mast year, seed production could be 24 times higher than during a non-mast year. As a result, the mast year maximum seed rain was 9020 seeds $\mathrm{m}^{-2}$, whereas in the lowest seed production year, this value only reached 8 seeds $\mathrm{m}^{-2}$ (Venturas et al. 2014b). Increased pollination efficiency in anemophilous species, and satiation of seed predators, are two factors which often favor the development of masting (Kelly \& Sork 2002). Taking into consideration that the spatial distribution of $U$. laevis has never been large, it is unlikely that this species could control seed predator populations by masting, especially not those of highly mobile seed predators such as birds, which are attracted by large seed crops (Perea et al. 2013). In light of this, masting probably evolved as a result of increased pollination efficiency in $U$. laevis (Venturas et al. 2014b).

Seed predation is an important selective pressure which drives the evolution of seed characteristics (Janzen 1969). Parthenocarpy and empty fruit formation, which are common in elms (López-Almansa \& Gil 2003, López-Almansa et al. 2004), act as a mechanism that enhances plant fitness by reducing pre- and post-dispersal seed predation (Ghazoul \& Satake 2009, Perea et al. 2013). Birds are the main pre-dispersal predators, consuming up to $98 \%$ of full seeds in nonmast years (Venturas et al. 2014b). Rodents are the main post-dispersal predators, and can cause local seed extinction, especially under shrub cover, which is their favorite microhabitat (Hulme \& Borelli 1999, Hulme \& Hunt 1999, Perea et al. 2013). Therefore, open microhabitats created by floods are also of great importance to recruitment from a seed survival perspective (Venturas et al. 2014b).

Vegetative propagation mechanisms (root suckers and stool-shoots) may be important for $U$. laevis regeneration and colonization of new sites after flooding disturbance in riparian formations (Collin 2003, Deiller et al. 2003). No root-suckers were observed in two Spanish wetland stands, but stool-shoots could have helped these populations to maintain genetic diversity levels after tree felling (Venturas et al. 2013a).

\section{Conservation of Spanish populations}

Spanish $U$. laevis populations are vulnerable to genetic drift, bottlenecks and stochastic events due to their small size and fragmentation (Fuentes-Utrilla et al. 2014). However, the greatest risk for these populations is human-induced habitat transformation. For example, the population of Palazuelos de Eresma (Segovia - PAL in Fig. 3) lost $22 \%$ of its mature elms and cannot naturally regenerate because it was transformed into a golf course and housing complex (Venturas et al. 2013a, Fuentes-Utrilla et al. 2014). Valdelatas stand (Madrid - VAL in Fig. 3) lacks sufficient recruitment due to underground water-table loss caused by overexploitation of Madrid's aquifer (Venturas et al. 2013a, 2014b). Flow regulation of Mediterranean rivers also negatively affects the dispersal, recruitment and establishment of hardwoods due to decreased water discharge and increased flood control after damming (Nilsson \& Bergren 2000, Nilsson et al. 2010, Bejarano et al. 2012). Long term conservation of $U$. laevis requires restoration of hydrological regimes, and the re-establi- shment of ecological patterns and processes where they have been destroyed by humans (Howe \& Miriti 2004), taking into consideration landscape ecology concepts (Lafortezza et al. 2013).

According to the International Union for Conservation of Nature's (IUCN) Red List Criteria (IUCN 2001) U. laevis should be considered as "critically endangered" in the Iberian Peninsula because: (i) it is native; (ii) its populations cover an area smaller than 10 $\mathrm{km}^{2}$; and (iii) it is suffering a decline in habitat quality and number of adult individuals (Fuentes-Utrilla et al. 2014). In light of this, SECBP is currently working for the inclusion of $U$. laevis in the Red List of Spanish Vascular Flora (Anonymous 2000), thus meaning it would be protected by national laws. Moreover, Mediterranean riparian forests with $U$. laevis should be included as a "natural habitat type of community interest", under Section 92 of the Habitat and Species Directive (Council Directive 92/43/EEC), in order to strengthen $U$. laevis conservation within Natura 2000 Network (FuentesUtrilla et al. 2014).

The first steps towards conservation of Spanish U. laevis populations have already been initiated by the SECBP. An inventory of the occurrence of the species is the first prerequisite for establishing any gene conservation programme (Eriksson 2001). SECBP already has an inventory of the populations, but it is still gathering more information on $U$. laevis occurrence, abundance and stand characteristics. Acquiring genetic information is of great importance when it comes to ensuring genetic variation is withheld in conservation programmes (Eriksson 2001, Goodall-Copestake et al. 2005). It is also necessary for defining evolutionary significant units, and management units within these, upon which conservation measures should be based (Moritz 2002). Genetic knowledge regarding certain Spanish white elm populations has served well to define management units (Fuentes-Utrilla et al. 2014). However, it would be interesting to complete the analyses with populations which have not yet been sampled (Fig. 3). For example, a recent survey on the population of Las Navas (Huelva - NAV in Fig. 3) has shown that it is constituted by trees with both haplotypes $A$ and $B$, extending further south the presence of haplotype $B$ (Diego Maya \& SECBP, unpublished data).

Several in situ and ex situ conservation measures have been proposed for elms (Collin et al. 2004). Whenever possible, in situ conservation should be carried out as it enables dynamic adaptation. To avoid the potential loss of additive variance, the effective population size $\left(N_{\mathrm{e}}\right)$ to preserve should be larger than 50. Conversely, in situ stands should contain 150-200 individuals (Eriksson 2001). In situ conservation is currently 
Fig. 3 - Spanish Ulmus laevis populations' genetic knowledge and ex situ conservation sites. Populations on which genetic studies have been performed (circles), populations on which genetic knowledge is lacking

(grey squares) and ex situ conservation sites (yellow triangles). Populations with chloroplast DNA (cpDNA) haplotype $A$ (blue circles); populations with cpDNA haplotype $B$ (red circles); populations containing both $A$ and $B$ cpDNA haplotypes (green circles). Data: Fuentes-Utrilla et al. (2014), Venturas et al. (2013a), and SECBP unpublished data.

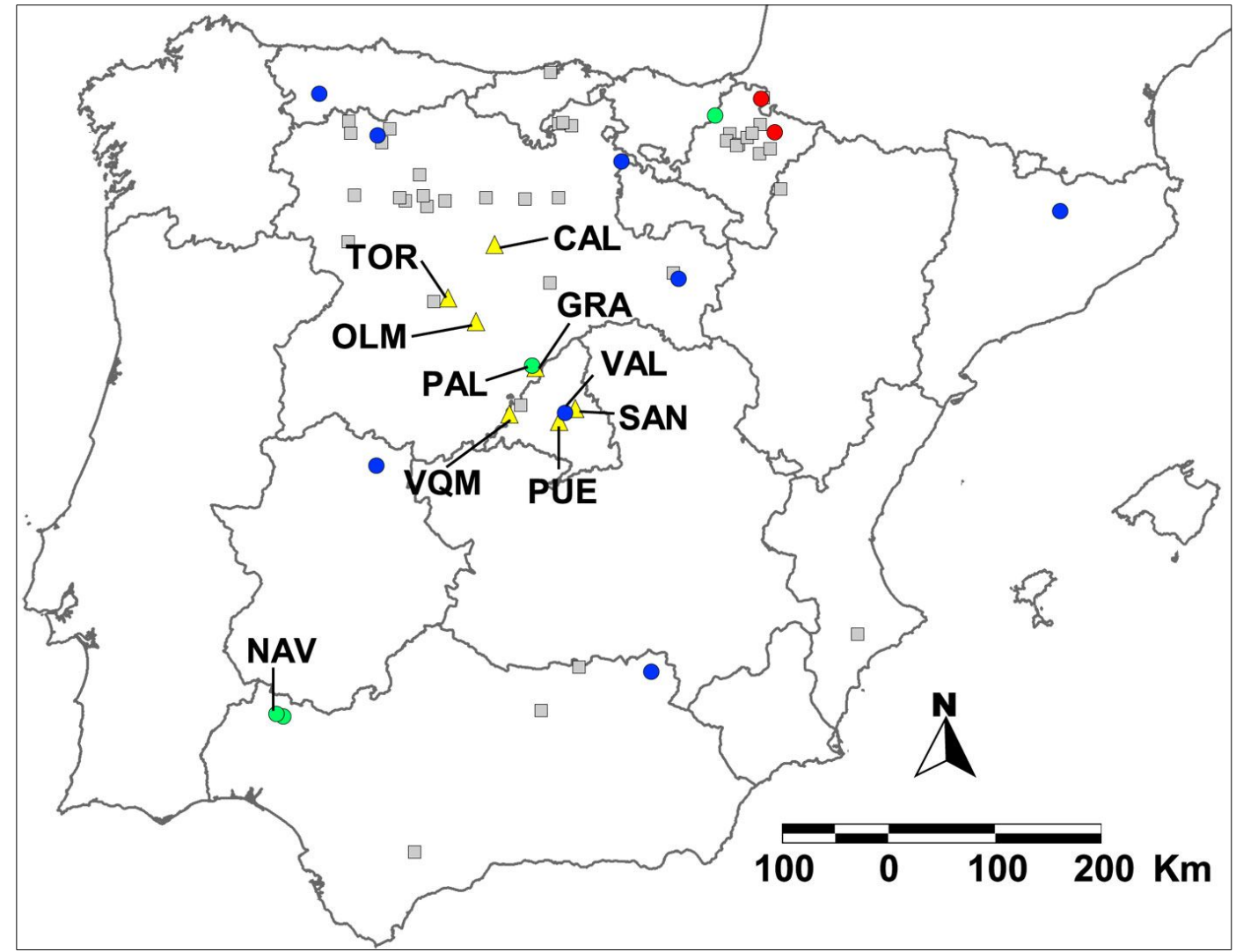

only being carried out in Valdelatas (Madrid). As $N_{\mathrm{e}}$ has been estimated at approximately 30 individuals (Venturas et al. 2013a), the first measure taken was to increase population size (53 mature trees) using seedlings grown from seeds collected in the stand. Ex situ conservation of Valdelatas is also being implemented by planting seedlings from this provenance in the Viñuelas stream (350 individuals; San Sebastián de los Reyes, Madrid - SAN in Fig. 3), and in the gardens (90 individuals) of Valdequemada municipality (Madrid - VQM in Fig 3). SECBP has already established three seed-orchards with approximately 300 seedlings, each belonging to 65 families from Palazuelos de Eresma (Segovia - PAL in Fig 3 ). These are located in Calabazanos (Palencia - CAL in Fig. 3), Tordesillas (Valladolid - TOR in Fig. 3) and La Granja de San Ildefonso (Segovia - GRA in Fig. 3). A re-forestation scheme with 2220 individuals from 18 families of Palazuelos de Eresma has also been carried out at the confluence of Adaja and Eresma rivers (Olmedo, Valladolid OLM in Fig. 3), in order to allow for dynamic ex situ conservation. A few genotypes (37) from nine Spanish provenances have also been planted in the conservation orchard of Puerta de Hierro (Madrid - PUE in Fig. 3). Furthermore, in situ conservation activities should also be carried out to increase the size of other populations. Optimizing canopy irradiation by thinning has been propo- sed as an appropriate method to increase elm stand vitality in the Czech Republic (Srámek \& Cermák 2012). Despite Iberian white elm stands having a different structure, the felling of competing vegetation might help increase elms' vitality, and create clearings in the riparian forest where elm seedlings can establish themselves.

Cryopreservation of seeds is a relatively cheap and easy static way in which to preserve the genetic resources of $U$. laevis (Collin et al. 2004). Whilst there is a European cryobank with Ulmus spp. resources (Harvengt et al. 2004), it does not contain U. laevis from Spain because at the time when the bank was established the taxon was not yet considered an indigenous species. Future work should focus on cryopreserving seeds from a wide range of Spanish U. laevis populations.

Finally, the conservation of $U$. laevis would produce extra benefits beyond the species' conservation itself, particularly when it occurs in a multifunctional landscape. Ulmus laevis has been identified as a good choice for floodplain reforestations (Mackenthun 2004) because it is less likely to be affected by DED than $U$. minor (Webber 2004), and due to its ability to survive long flooding periods (Collin 2003). The latter is an important issue for forest planning as extreme flooding events are expected to occur more frequently in central and western Europe as a consequence of climate change (Glenz et al. 2006, Kramer et al. 2008).
Restoration of river banks with $U$. laevis could also be beneficial for the conservation of granivorous fauna due to the large seedcrops it produces even in non-mast years (Perea et al. 2013, Venturas et al. 2014b). White elm has been shown to be important for the conservation of epiphytic bryophyte and lichen communities in Latvia (Mežaka et al. 2012), as well as for millipede (Diplopoda) communities in Slovakia (Stašiov et al. 2012). Moreover, extracts from $U$. laevis may also be useful for developing drugs against cancer (Paschke et al. 2009, Hartmann et al. 2011). Conservation activities are now more likely to occur and succeed since all of the research work outlined above has led to confirmation of $U$. laevis' autochthonous status and made it possible to delineate its ecology in the Iberian Peninsula.

\section{Acknowledgements}

We would like to thank Eudaldo González for the elm surveys he has carried out all over Spain, and Diego Maya for collecting samples in Huelva. We are also grateful to Pablo Sanjuanbenito, and Cuenca Alta del Manzanares, park managers, for their support. This study was funded by the Ministerio de Agricultura, Alimentación y Medio Ambiente (MAGRAMA), and by the Comunidad de Madrid (project S2009AMB1668). M.V. was sponsored by a Technical University of Madrid "PIF" Pre-Doctoral 


\section{Fellowship.}

In memoriam of Margarita Burón. She was the first member of SECBP to consider that $U$. laevis could be native to Spain.

\section{References}

Abadía J, Vázquez S, Rellán-Álvarez R, El-Jendoubi $\mathrm{H}$, Abadía $\mathrm{A}$, Álvarez-Fernández $\mathrm{A}$, López-Millán AF (2011). Towards a knowledgebased correction of iron chlorosis. Plant Physiology and Biochemistry 49: 471-482. - doi: 10.10 16/j.plaphy.2011.01.026

Aizpuru I, Aseginolaza C, Uribe-Echebarría PM, Urrutia P, Zorrakin I (1999). Claves ilustradas de la flora del País Vasco y territorios limítrofes [Illustrated key for the flora of the Basque Country and neighboring regions]. Servicio Central de Publicaciones del Gobierno Vasc, Vitoria, Spain, pp. 99-100. [in Spanish]

Allen CD, Macalady AK, Chenchouni H, Bachelet $\mathrm{D}$, McDowell N, Vennetier M, Kitzberger T, Rigling A, Breshears DD, Hogg EHT, Gonzalez P, Fensham R, Zhang Z, Castro J, Demidova N, Lim JH, Allard G, Running SW, Semerci A, Cobb N (2010). A global overview of drought and heat-induced tree mortality reveals emerging climate change risk for forests. Forest Ecology and Management 259: 660-684. - doi: 10.1016/ j.foreco.2009.09.001

Amo M (1871). Flora fanerogámica de la península ibérica o descripción de las plantas cotiledóneas que crecen en España y Portugal [Phanerogam flora of the Iberian Peninsula or description of the cotyledonous plants growing in Spain and Portugal]. Tomo II. Granada, Spain, pp. 81-83. [in Spanish]

Anonymous (2000). Lista roja de flora vascular española (valoración según categorías UICN) [Red list of the Spanish vascular flora (assessment following IUCN criteria)]. Conservación Vegetal 6: 11-38. [in Spanish]

Barigah TS, Charrier O, Douris M, Bonhomme M, Herbette S, Améglio T, Fichot R, Brignolas F, Cochard H (2013). Water stress-induced xylem hydraulic failure is a causal factor of tree mortality in beech and poplar. Annals of Botany 112: 1431-1437. - doi: 10.1093/aob/mct204

Bejarano MD, González del Tánago M, de Jalón DG, Marchamalo M, Sordo-Ward A, SolanaGutiérrez J (2012). Responses of riparian guilds to flow alterations in a Mediterranean stream. Journal of Vegetation Science 23: 443-458. doi: 10.1111/j.1654-1103.2011.01360.x

Black-Samuelsson S, Whiteley RE, Junzhan G (2003). Growth and leaf morphology response to drought stress in the riparian broadleaved tree, Ulmus laevis (Pall.). Silvae Genetica 52: 292299. [online] URL: http://silvaegenetica.com/ fileadmin/content/dokument/archiv/silvaegenetica/52 2003/52-5-6-292.pdf

Blom CWPM, Voesenek LACJ (1996). Flooding: the survival strategies of plants. Trends in Ecology and Evolution 11: 290-295. - doi: 10.1016/ 0169-5347(96)10034-3

Brasier CM (2000). Intercontinental spread and continuing evolution of the Dutch elm disease pathogens. In: "The elms: breeding conservation and disease management" (Dunn CP ed). Kluwer Academic Publisher, Boston, USA, pp. 61-72.

Casadevall J, Font i Quer P (1933). Flora de Catalunya (vol. 5). Institud d'Estudis Catalan, Barcelona, Spain, pp. 153-154. [in Spanish]

Ceballos L (1966). Mapa forestal de España, escala 1:400.000 [Forest map of Spain, scale 1:400.000]. Dirección General de Montes, Caza y Pesca Fluvial, Madrid, Spain.

Ciçek E, Tilki F (2005). Seed germination of three Ulmus species from Turkey as influenced by temperature and light. Journal of Enviromental Biology 28: 423-425.

Ciçek E, Tilki F, Kulaç S, Yilmaz M, Yilmaz F (2007). Survival and growth of three hardwood species (Fraxinus angustifolia, Ulmus laevis and $U$. minor) on a bottomland site with heavy clay soil. Journal of Plant Sciences 2: 233-237. - doi: 10.3923/jps.2007.233.237

Cogolludo-Agustín MA, Agúndez D, Gil L (2000). Identification of native and hybrid elms in Spain using isozyme gene markers. Heredity 85: 157-166. - doi: 10.1046/j.1365-2540.2000. 00740.x

Collin E (2003). EUFORGEN Technical Guidelines for genetic conservation and use for European white elm (Ulmus laevis). International Plant Genetic Resources Institute (IPGRI), Rome, Italy, pp. 6

Collin E, Bilger I, Eriksson G, Turok J (2000). The conservation of elm genetic resources in Europe. In: "The elms: breeding, conservation, and disease management" (Dunn CP ed). Kluwer Academic Publisher, Boston, USA, pp. 281-293. Collin E, Rusanen M, Ackzell L, Bohnens J, de Aguiar A, Diamandis S, Franke A, Gil L, Harvengt $L$, Hollingsworth $P$, Jenkins $G$, MeierDinkel A, Mittempergher L, Musch B, Nagy L, P'ques M, Pinon J, Piou D, Rotach P, Santini A, Vanden Broeck A, Wolf H (2004). Methods and progress in the conservation of elm genetic resources in Europe. Investigaciones Agrarias: Sistemas y Recursos 13: 261-272.

Costa AC (1864). Introducción a la flora de Cataluña y catálogo razonado de las plantas observadas en esta region [Introduction to the flora of Catalonia and reasoned catalogue of the observed plants in this region]. Imprenta del Diario de Barcelona, Barcelona, Spain, pp. 225. [in Spanish]

Deiller AF, Walter JMN, Trémolières M (2003). Regeneration strategies in a temperate hardwood floodplain forest of the Upper Rhine: sexual versus vegetative reproduction of woody species. Forest Ecology and Management 180: 215-225. doi: 10.1016/S0378-1127(02)00600-X

Eriksson G (2001). Conservation of noble hardwoods in Europe. Canadian Journal of Forest Research 31: 577-587. - doi: 10.1139/x00-134

Fuentes-Utrilla P (2008). Estudio de la variabilidad genética del género Ulmus L. en España mediante marcadores moleculares [Study of genetic variability of genus Ulmus L. in Spain using molecular markers]. PhD Thesis, Departamento de Silvopascicultura, Universidad Politécnica de
Madrid, Madrid, Spain, pp. 146. [in Spanish] Fuentes-Utrilla P, Venturas M, Hollingsworth PM, Squirrell J, Collada C, Stone GN, Gil L (2014). Extending glacial refugia for a European tree: genetic markers show that Iberian populations of white elm are native relicts and not introductions. Heredity 112: 105-113. - doi: 10.1038/ hdy.2013.81

Ghazoul J, Satake A (2009). Nonviable seed set enhances plant fitness: the sacrificial sibling hypothesis. Ecology 90: 369-377. - doi: 10.1890/ 07-1436.1

Gil L, García-Nieto ME (1990). Paleobotánica e historia de los olmos de la Península Ibérica $[\mathrm{Pa}-$ leobotany and the history of elms in the Iberian Peninsula]. In: "Los olmos y la grafiosis en España" (Gil L ed). Ministerio de Agricultura, Pesca y Alimentación - ICONA, Madrid, Spain, pp. 29-65. [in Spanish]

Gil L, Fuentes-Utrilla P, Soto A, Cervera MT, Collada C (2004). English elm is a 2000-yearold Roman clone. Nature 431: 1053. - 10.1038/ 4311053a

Glenz C, Schlaepfer R, Iorgulescu I, Kienast F (2006). Flooding tolerance of Central European tree and shrub species. Forest Ecology and Management 235: 1-13. - doi: 10.1016/j.foreco.20 06.05 .065

Goodall-Copestake WP, Hollingsworth ML, Hollingsworth PM, Jenkins GI, Collin E (2005). Molecular markers and ex situ conservation of the European elms (Ulmus spp.). Biological Conservation 122: 537-546. - doi: 10.1016/j.biocon. 2004.09.011

Hartmann AM, Abarzua S, Schlichting A, Richter DU, Leinweber P, Briese V (2011). Effects of elm bark extracts from Ulmus laevis on human chorion carcinoma cell lines. Archives of Gynecology and Obstetrics 284: 1265-1269. - doi: 10.1007/s00404-010-1830-5

Harvengt L, Meier-Dinkel A, Dumas A, Collin E (2004). Establishment of a cryopreserved gene bank of European elms. Canadian Journal of Forest Research 34: 43-55. - doi: 10.1139/x03193

Hemery GE, Clark JR, Aldinger E, Claessens H, Malvolti ME, O’Connor E, Raftoyannis Y, Savill PS, Brus R (2010). Growing scattered broadleaved tree species in Europe in a changing climate: a review of risks and opportunities. Forestry 83: 65-81. - doi: 10.1093/forestry/cpp034 Heuertz M, Fineschi S, Anzidei M, Pastorelli R, Salvini D, Paule L, Frascaria-Lacoste N, Hardy O, Vekemans X, Vendramin GG (2004). Chloroplast DNA variation and postglacial recolonization of common ash (Fraxinus excelsior L.) in Europe. Molecular Ecology 13: 3437-3452. doi: 10.1111/j.1365-294X.2004.02333.X

Hooke JM (2006). Human impacts on fluvial systems in the Mediterranean region. Geomorphology 79: 311-355. - doi: 10.1016/j.geomorph.2006. 06.036

Howe HF, Miriti MN (2004). When seed dispersal matters. BioScience 54: 651-660. - doi: 10.1641/ 0006-3568(2004)054[0651:WSDM]2.0.CO;2 Hulme PE, Borelli T (1999). Variability in post- 
dispersal seed predation in deciduous woodland relative importance of location, seed species, burial and density. Plant Ecology 145: 149-156. - doi: 10.1023/A:1009821919855

Hulme PE, Hunt M (1999). Rodent post-dispersa seed predation in deciduous woodland: predator response to absolute and relative abundance of prey. Journal of Animal Ecology 68: 417-428. doi: 10.1046/j.1365-2656.1999.00294.x

Huntley B, Birks H (1983). Atlas of past and present pollen maps for Europe 0-13.000 years ago. Cambridge University Press, Cambridge, UK, pp. 667.

IUCN (2001). IUCN Red list categories and criteria: version 3.1. IUCN Species Survival Commission, Gland, Cambridge, UK, pp. 32.

Janzen DH (1969). Seed eaters versus seed size, number, toxicity and dispersal. Evolution 23: 127. - doi: $10.2307 / 2406478$

Kelly D, Sork VL (2002). Mast seeding in perennial plants: why, how, where? Annual Review of Ecology and Systematics 33: 427-447. - doi: 10.1146/annurev.ecolsys.33.020602.095433

King RA, Ferris C (1998). Chloroplast DNA phylogeography of Alnus glutinosa (L.) Gaertn. Molecular Ecology 7: 1151-1161. - doi: 10.1046/ j.1365-294x.1998.00432.x

Kobayashi T, Nishizawa NK (2012). Iron uptake, translocation, and regulation in higher plants. Annual Review of Plant Biology 63: 131-152. doi: 10.1146/annurev-arplant-042811-105522

Kozlowski TT (1997). Responses of woody plants to flooding and salinity. Tree Physiology Monographs 1: 1-29. [online] URL: http://www.pucrs.br/fabio/fisiovegetal/Encharcamento.pdf

Kramer K, Vreugdenhil SJ, van der Werf DC (2008). Effects of flooding on the recruitment, damage and mortality of riparian tree species: a field and simulation study on the Rhine floodplain. Forest Ecology and Management 255: 3893-3903. - doi: 10.1016/j.foreco.2008.03.044

Lafortezza R, Sanesi G, Chen J (2013). Largescale effects of forest management in Mediterranean landscapes of Europe. iForest 6: 331-335. - doi: 10.3832/ifor0941-006

Laguna M, de Ávila P (1883). Flora forestal española, que comprende la descripción de los árboles, arbustos y matas que se crían silvestres o asilvestradas en España [Spanish forest flora, which includes the description of trees, shrubs and bushes that are grown wild or naturalized in Spain]. Colegio Nacional de Sordo-Mudos y de Ciegos, Madrid, Spain, pp. 280-287. [in Spanish]

Lapeyrouse P (1813). Histoire abrégée des plantes des Pyrénées et itinéraire des botanistes dans ces montagnes [Short history of the plants of the Pyrenees and route followed by the botanists in these mountains]. L'Imprimerie de Bellegarrigue, Toulouse, France, pp. 131-132. [in French]

Larbi A, Abadía A, Abadía J, Morales F (2006). Down co-regulation of light absorption, photochemistry, and carboxylation in $\mathrm{Fe}$ deficient plants growing in different environments. Photosynthesis Research 89: 113-126. - doi: 10.1007/ s11120-006-9089-1
Loscos F, Pardo J (1866). Serie imperfecta de las plantas aragonesas espontáneas, particularmente de las que habitan la parte meridional [Imperfect series of spontaneous Aragonese plants, particularly those living in the southern part of the region]. Imprenta de Ulpiano Huerta, Alcañiz, Spain, pp. 372. [in Spanish]

López R (2003). Paleobotánica de los olmos [Paleobotany of elms]. In: "Los olmos ibéricos. Conservación y mejora frente a la grafiosis" (Gil L, Solla A, Iglesias S eds). Organismo Autónomo de Parques Nacionales, Madrid, Spain, pp. 4968. [in Spanish]

López R, López de Heredia U, Collada C, Cano FJ, Emerson BC, Cochard H, Gil L (2013). On vulnerability to cavitation, hydraulic efficiency, growth and survival in an insular pine (Pinus canariensis). Annals of Botany 111: 1167-1179. doi: $10.1093 / \mathrm{aob} / \mathrm{mct} 084$

López-Almansa JC, Gil L (2003). Empty samara and parthenocarpy in Ulmus minor s.1. in Spain. Silvae Genetica 52: 241-243. [online] URL: http://xn--rheinischesmuseumfrphilologie-2bd.com/fileadmin/content/dokument/archiv/silvaegenetica/52_2003/52-5-6-241.pdf

López-Almansa JC (2004). Reproductive ecology of riparian elms. Investigaciones Agrarias: Sistemas y Recursos Forestales 13: 17-27.

López-Almansa JC, Yeung EC, Gil L (2004). Abortive seed development in Ulmus minor Mill. Botanical Journal of the Linnean Society 145: 455-467. - doi: 10.1111/j.1095-8339.2004.002 97.x

Machon N, Lefranc M, Bilger I, Henry JP (1995). Isoenzymes as an aid to clarify the taxonomy of French elms. Heredity 74: 39-47. - doi: 10.1038/ hdy. 1995.5

Machon N, Lefranc M, Bilger I, Mazer SJ, Sarr A (1997). Allozyme variation in Ulmus species from France: analysis of differentiation. Heredity 78: 12-20. - doi: 10.1038/hdy.1997.2

Mackenthun GL (2004). The role of Ulmus laevis in German floodplain landscapes. Investigaciones Agrarias: Sistemas y Recursos 13: 55-63.

Magri D, Vendramin GG, Comps B, Dupanloup I, Geburek T, Gömöry D, LataÅowa M, Litt T, Paule L, Roure JM, Tantau I, van der Knaap WO, Petit RJ, de Beaulieu JL (2006). A new scenario for the Quaterny history of European beech populations: palaeobotanical evidence and genetic consequences. New Phytologist 171: 199221. - doi: 10.1111/j.1469-8137.2006.01740.x

Marschner H, Römheld V (1994). Strategies of plants for acquisition of iron. Plant and Soil 165: 261-274. - doi: 10.1007/BF00008069

Martín-Benito D, García-Vallejo MC, Pajares JA, López D (2005). Triterpenes in elms in Spain. Canadian Journal of Forest Research 35: 199 205. - doi: 10.1139/x04-158

Messenger S (1986). Alkaline runoff, soil $\mathrm{pH}$ and white oak manganese deficiency. Tree Physiology 2: 317-325. - doi: 10.1093/treephys/2.1-23.317

Mežaka A, Brumelis G, Piterans A (2012). Tree and stand-scale factors affecting richness and composition of epiphytic bryophytes and lichens in deciduous woodland key habitats. Biodiversity and Conservation 21: 3221-3241. - doi: 10.1007/s10531-012-0361-8

Mittempergher L, La Porta N (1991). Hybridization studies in the Eurasian species of elm ( $U l$ mus spp.). Silvae Genetica 40: 237-243.

Moritz C (2002). Strategies to protect biological diversity and the evolutionary processes that sustain it. Systematic Biology 51: 238-254. - doi: 10.1080/10635150252899752

Navarro C, Castroviejo S (1993). Ulmus. In: "Flora Ibérica. Vol. III. Plumbaginaceae (partim) - Capparaceae" (Castroviejo et al. eds). Real Jardín Botánico, CSIC, Madrid, Spain, pp. 244248.

Nielsen LR, Kjær ED (2010). Fine-scale gene flow and genetic structure in a relic Ulmus laevis population at its northern range. Tree Genetics and Genomes 6: 643-649. - doi: 10.1007/s11295-010 -0280-3

Niinemets U, Valladares F (2006). Tolerance to shade, drought, and waterlogging of temperate hemisphere trees and shrubs. Ecological Monographs 76: 521-547. - doi: 10.1890/0012-9615 (2006)076[0521:TTSDAW]2.0.CO;2

Nilsson C, Bergren K (2000). Alterations of riparian ecosystems caused by river regulation. BioScience 50: 783-792. - doi: 10.1641/0006-3568 (2000)050[0783:AORECB]2.0.CO;2

Nilsson C, Brown RL, Jansson R, Merritt DM (2010). The role of hydrochory in structuring riparian and wetland vegetation. Biological Reviews 85: 837-858

Paal J, Rannik R, Jeletsky EM, Prieditis N (2007). Floodplain forests in Estonia: typological diversity and growth conditions. Folia Geobotanica 42: 383-400. - doi: 10.1007/BF02861701

Pajares JA, García S, Díez JJ, Martín D, GarcíaVallejo MC (2004). Feeding responses by Scolytus scolytus to twig bark extracts from elms. Investigaciones Agrarias: Sistemas y Recursos Forestales 13: 217-225.

Paschke D, Abarzua S, Schlichting A, Richter DU, Leinweber P, Briese V (2009). Inhibitory effects of bark extracts from Ulmus laevis on endometrial carcinoma: an in-vitro study. European Journal of Cancer Prevention 18(2): 162-168. doi: 10.1097/CEJ.0b013e32831bc546.

Pastor P (1853). Diagnóstico agrícola sobre la provincia de Asturias [Agricultural diagnostic of Asturias province]. Memoria de la Real Academia de Ciencias de Madrid, Tomo 1, Parte 3. Madrid, Spain, pp. 38. [in Spanish]

Perea R, Venturas M, Gil L (2013). Empty seeds are not always bad: Simultaneous effect of seed emptiness and masting on animal seed predation. Plos One 8 (6): e65573. - doi: 10.1371/journal. pone.0065573

Petit RJ, Csaikl UM, Bordács S, Burg K, Coart E, Cottrell J, van Dam B, Deans JD, DumolinLapègue S, Fineschi S, Finkeldey R, Gillies A, Glaz I, Goicoechea PG, Jensen JS, König AO, Lowe AJ, Madsen SF, Mátyás G, Munro RC, Olalde M, Pemonge MH, Popescu F, Slade D, Tabbener H, Taurchini D, de Vries SG, Ziegenhagen B, Kremer A (2002). Chloroplast DNA 
variation in European white oaks. Forest Ecology and Management 156 (1-3): 5-26. - doi: 10.101 6/S0378-1127(01)00645-4

Pezeshki SR (2001). Wetland plant response to soil flooding. Environmental and Experimental Botany 46: 299-312. - doi: 10.1016/S0098-8472 (01)00107-1

Pinon J, Husson C, Collin E (2005). Susceptibility of native French elm clones to Ophiostoma novo-ulmi. Annals of Forest Science 62: 689696. - doi: 10.1051/forest:2005066

Richens RH, Jeffers JR (1986). Numerical taxonomy and ethnobotany of elms of Northern Spain. Anales del Jardín Botánico de Madrid 42: 325 341.

Ruíz de la Torre J (1971). Árboles y arbustos de la España peninsular [Trees and shrubs of peninsular Spain] ( $1^{\text {st }}$ edn). ETSI de Montes, Madrid, Spain, pp. 512. [in Spanish]

Schweingruber FH (1990). Anatomy of European woods: an atlas for the identification of European trees, shrubs and dwarf shrubs. Paul Haupt Berne and Stuttgart Publishers, Bern, Switzerland, pp. 726-727.

Segura A (1973). De la flora Soriana y circumsoriana [On the flora of Soria and its surroundings]. Pirineos 109: 35-49. [in Spanish]

Solla A, Bohnens J, Collin E, Diamandis S, Franke A, Gil L, Burón M, Santini A, Mittempergher L, Pinon J, Vanden Broeck A (2005). Screening European elms for resistance to Ophiostoma novo-ulmi. Forest Science 51: 134-141.

Somot S, Sevault F, Déqué M, Crépon M (2008). $21^{\text {st }}$ century climate change scenario for the Mediterranean using a coupled AtmosphereOcean Regional Climate Model. Global and Planetary Change 63: 112-126. - doi: 10.1016/j.gloplacha.2007.10.003

Sperry JS, Meinzer FC, McCulloh KA (2008). Safety and efficiency conflicts in hydraulic architecture: Scaling from tissues to trees. Plant, Cell and Environment 31: 632-645. - doi: 10.1111/j. 1365-3040.2007.01765.x

Srámek M, Cermák J (2012). The vertical leaf dis tribution of Ulmus laevis Pall. Trees - Structure and Function 26: 1781-1792. - doi: 10.1007/s0 0468-012-0747-y

Stafford PJ (1995). The northwest European pollen flora. Ulmaceae. Review of Palaeobotany and Palynology 88: 25-46. - doi: 10.1016/00346667(95)98770-8

Stašiov S, Stašiová A, Svitok M, Michalková E, Slobodník B, Lukáčik I (2012). Millipede (Diplopoda) communities in an arboretum: influence of tree species and soil properties. Biologia 67: 945-952. - doi: 10.2478/s11756-012-0097-7 Stone GN, Sunnucks P (1993). Genetic consequences of an invasion through a patchy environment - the cynipid gallwasp Andricus kollari. Molecular Ecology 16: 2768-2781. - doi:
10.1111/j.1365-294X.2007.03348.x

Svenning JC, Normand S, Kageyama M (2008). Glacial refugia of temperate trees in Europe: insights from species distribution modelling. Journal of Ecology 96: 1117-1127. - doi: 10.1111/ j.1365-2745.2008.01422.x

Thomas FM, Brandt T, Hartmann G (1998). Leaf chlorosis in pedunculate oaks (Quercus robur $\mathrm{L}$ ) on calcareous soils resulting from lime-induced manganese iron-deficiency: Soil conditions and physiological reactions. Angewandte Botanik 72: 28-36.

Timbal J, Collin E (1999). L'orme lisse (Ulmus laevis Pallas) dans le Sud de la France: repartition et stratégie de conservation des ressources génétiques [European white elm in southern France: distribution and conservation strategy of its genetic resources]. Revue Forestière Française 51: 593-604. [in French] - doi: 10.4267/2042/ 5468

Tyler G (1992). Inability to solubilize phosphate in limestone soils - key factor controlling calcifuge habit of plants. Plant and Soil 145: 65-70. doi: 10.1007/BF00009542

Vakkari P, Rusanen M, Karkkainen K (2009). High genetic differentiation in marginal populations of European white elm (Ulmus laevis). Silva Fennica 43: 185-196. - doi: 10.14214/sf.205

Valbuena-Carabaña M, López-de-Heredia U, Fuentes-Utrilla P, González-Doncel I, Gil L (2010). Historical and recent changes in Spanish forests: a socioeconomic process. Review of Palaeobotany and Palynology 162: 492-506. - doi: 10.1016/ j.revpalbo.2009.11.003

Vander Mijnsbrugge K, Vanden Broeck A, Van Slycken J (2005). A survey of Ulmus laevis in Flanders (Northern Belgium). Belgian Journal of Botany 138: 199-204.

Vander Wall SB, Longland WS (2004). Diplochory: are two seed dispersers better than one? Trends in Ecology and Evolution 19: 155-161. doi: $10.1016 /$ j.tree.2003.12.004

Venturas M (2013). Estudio de la ecología de $U l$ mus laevis Pallas en la Península Ibérica [Study of the ecology of Ulmus laevis Pallas in the Iberian Peninsula]. PhD Thesis, Departamento de Silvopascicultura, Universidad Politécnica de Madrid, Madrid, Spain, pp. 105. [in Spanish]

Venturas M, Fuentes-Utrilla P, Ennos R, Collada C, Gil L (2013a). Human induced changes on fine-scale genetic structure in Ulmus laevis Pallas wetland forests at its SW distribution limit. Plant Ecology 214: 317-327. - doi: 10.1007/s112 58-013-0170-5

Venturas M, López R, Gascó A, Gil L (2013b). Hydraulic properties of European elms: xylem safety-efficiency tradeoff and species distribution in the Iberian Peninsula. Trees - Structure and Function 27: 1691-1701. - doi: 10.1007/s00
468-013-0916-7

Venturas M, Nanos N, Gil L (2014a). The reproductive ecology of Ulmus laevis Pallas in a transformed habitat. Forest Ecology and Management 312: 170-178. - doi: 10.1016/j.foreco.2013.10. 007

Venturas M, Fernandez V, Nadal P, Lucena JJ, Guzman P, Gil L (2014a). Root iron uptake efficiency of Ulmus laevis and U. minor and their distribution in soils of the Iberian Peninsula. Frontiers in Plant Science 5: 104. - doi: 10.3389/ fpls.2014.00104

Webber JF, Kirby JN (1983). Host feeding preference of Scolytus scolytus. In: "Research on Dutch elm disease in Europe" (Burdekin DA ed). Forestry Commission Bulletin 60, HMSO, London, UK, pp. 47-49.

Webber JF (2004). Experimental studies on factors influencing the transmission of Dutch elm disease. Investigaciones Agrarias: Sistemas y Recursos Forstales 13: 197-205.

Whiteley RE (2004). Quantitative and molecular genetic variation in Ulmus laevis Pall. PhD Thesis, Department of Plant Biology and Forest Genetics, Swedish University of Agricultural Sciences, Uppsala, Sweden, pp. 33.

Whiteley RE, Black-Samuelsson S, Clapham D (2003a). Development of microsatellite markers for the European white elm (Ulmus laevis Pall.) and cross-species amplification within the genus Ulmus. Molecular Ecology Notes 3: 598-600. doi: 10.1046/j.1471-8286.2003.00525.x

Whiteley RE, Black-Samuelsson S, Jansson G (2003b). Within and between population variation in adaptive traits in Ulmus laevis, the European white elm. Forest Genetics 10: 309-319.

Wiegrefe S, Sytsma KJ, Guries RP (1994). Phylogeny of elms (Ulmus, Ulmaceae): molecular evidence for a sectional classification. Systematic Botany 19: 590-612. - doi: 10.2307/2419779 Willkomm M, Lange J (1861). Prodromus Florae Hispanicae. Vol. I, Stuttgartiae, Germany, pp. 248-249.

Zohlen A, Tyler G (1997). Differences in iron nutrition strategies of two calcifuges, Carex pilulifera L. and Veronica officinalis L. Annals of Botany 80: 553-559. - doi: 10.1006/anbo.1997. 0493

Zohlen A, Tyler G (2000). Immobilization of tissue iron on calcareous soil: differences between calcicole and calcifuge plants. Oikos 89: 95-106. - doi: 10.1034/j.1600-0706.2000.890110.x

Zohlen A, Tyler G (2004). Soluble inorganic tissue phosphorus and calcicole-calcifuge behaviour of plants. Annals of Botany 94: 427-432. doi: $10.1093 / \mathrm{aob} / \mathrm{mch} 162$

Zohlen A (2002). Chlorosis in wild plants: is it a sing of iron deficiency? Journal of Plant Nutrition 25: 2205-2228. - doi: 10.1081/PLN-1200 14071 